\title{
ICAPP
}

\section{International Congress on Advances in Nuclear Power Plants}

\section{Présentation}

a RGN attache une importance toute particulière à se faire l'écho de grandes conférences ayant eu lieu en France en donnant une audience renouvelée à un certain nombre de présentations via l'édition d'un dossier.

Le présent numéro est consacré à la conférence ICAPP 2007 (International Congress on Advances in Nuclear Power Plants) qui a eu lieu du 14 au 16 mai 2007 à Nice (Acropolis). Le comité de rédaction a choisi 12 papiers présentés à cette conférence pour être repris dans cette édition [1]. Je voudrais chaleureusement remercier les auteurs pour le travail d'adaptation et de mise en forme effectué sur leur présentation afin d'en faire des textes de référence.

Je voudrais aussi dire la difficulté de ce même comité à se restreindre à un si petit nombre de présentations alors que, au cours de la conférence, de si nombreuses présentations auraient intéressé les lecteurs de la RGN [2].

Je pense en particulier, mais pas uniquement, aux présentations faites au cours des sessions plénières et reflétant les orientations stratégiques des principaux pays ayant déjà choisi l'option nucléaire comme une composante de leur production d'électricité, de ceux, de plus en plus nombreux qui confirment cette option ou de ceux s'apprêtant à faire des choix dans ce sens.

Le cas de l'Inde, représentée par les plus hauts responsables de l'industrie nucléaire de ce pays, est à cet égard exemplaire, qui montre à la fois une volonté politique de construction d'une capacité industrielle tout en mettant en exergue les difficultés spécifiques liées au statut de puissance nucléaire de ce pays sans être un "pays doté" au sens du TNP (Traité de Non Prolifération).

Les États-Unis sont un autre exemple des évolutions en cours avec tous les moyens que l'administration américaine a choisi de mettre en place pour susciter une reprise du nucléaire menée par l'industrie. L'évolution de la réflexion aux USA dans le domaine de la prise en compte de la fin de cycle est à cet égard révélatrice d'un réexamen de ces questions avec une perspective stratégique et de long terme. Mais la conférence a permis aussi de prendre connaissance des orientations d'autres pays (Allemagne, Belgique, Canada, Chine, Corée du Sud, France, Japon, Russie). Le point de vue des électriciens et des ingénieries est évidemment crucial dans la peinture de ce panorama du nucléaire que la conférence s'est attachée à tracer.

Mais ce numéro de la RGN a choisi de mettre en lumière certaines synthèses techniques sur des sujets ayant marqué des progrès sensibles ces dernières années. Certaines de ces présentations ont été faites au cours de "keynote sessions" pour presque tous les thèmes de la conférence. Ces sessions sont le résultat d'une innovation dans l'organisation de ce type de congrès en cherchant à mettre en exergue certains papiers dont la largeur de vue, la qualité de synthèse ou

[1] Une deuxième partie de ce dossier sera publiée dans RGN5/2007.

[2] Certaines autres présentations de sessions plénières et de keynotes sont disponibles sur le CD-ROM de la conférence. 
de revue d'un domaine technique appelait d'attirer l'attention des participants. Tenues en parallèle des autres sessions techniques, cela a pu, dans certains cas, créer des mises en parallèle de sessions qui ont pu être regrettées. Le bilan de cette expérience est néanmoins suffisamment positif pour que nous cherchions, en l'adaptant, à le reconduire dans les prochains congrès de cette nature mélangeant les thèmes généraux ou de stratégie et des thèmes plus techniques.

Vous trouverez donc, cher lecteur, des synthèses sur des sujets techniques particulièrement à l'ordre du jour dans un contexte de "Nuclear Renaissance at Work", sous-titre que nous avions choisi pour cette conférence.

Jean-Claude GAUTHIER

Areva NP

Président du comité technique

\section{Presentation}

$T$ he General Nuclear Review (RGN) makes it a point of honor to report on major conferences held in France, and makes a number of presentations available to a wider audience through its dedicated reports.

This edition focuses on the ICAPP 2007 conference held at the Acropolis Exhibition Center in Nice from 14 to 16 May. The editorial committee has selected 12 of the presentations made at the conference [3]. I would like to extend my warmest thanks to the authors for adapting the form and substance of their presentations to produce these reference documents.

Might I also add that it was no easy matter for the committee to select such a small number of presentations since so many of those given during the conference would undoubtedly have been of interest to RGN readers [4].

I am thinking essentially, but not only, of the presentations made during the plenary sessions which focused on the strategic orientations of the major countries that already have a nuclear power industry, those that are now opting for nuclear, and there are more and more of them, and others still that are on the verge of deciding to go down the nuclear road.

India, which was represented by its most senior nuclear industry officials, is a case in point, illustrating the political will to build up an industrial capacity but at the same time highlighting the specific problems in classifying the country as a nuclear power without it being a nuclear weapons state as defined in the Non-Proliferation Treaty.

Changes are also coming about in the US where the administration has taken a number of steps to promote a nuclear renaissance, spearheaded by industry. The country's shift in opinion concerning the end of the fuel cycle reveals that these issues are being reconsidered from a long-term strategic viewpoint. But the conference also provided an opportunity to find out about the orientations of other countries such as Germany, Belgium, Canada, China, South Korea, France, Japan and Russia. It goes without saying that the standpoints of utilities and engineering companies are an essential part of the overall picture of the nuclear industry that the conference attempted to paint.

[3] The second part of the report will be published in RGN5/2007.

[4] Other papers from the plenary sessions and keynotes are available on the CD-ROM of the conference. 
But this edition of RGN has chosen to spotlight a number of technical summaries in areas where considerable progress has been made in recent years. Some of the presentations were made during keynote sessions held on nearly all the conference topics. These sessions mark a departure from the traditional way in which conferences of this type are organized; they are designed to draw delegates' attention to certain papers deemed outstanding because of their broad views, conciseness and technical quality. Unfortunately they ran concurrently with other technical sessions and some conflicts were inevitable. Generally speaking, however, the experience was positive and we will be attempting to adapt it for future conferences to create a melting pot of general or strategic topics and other more technical issues.

The report contains some of the predominant technical issues addressed in the context of "Nuclear Renaissance at Work", the title chosen for this year's conference.

I wish you a fruitful and enriching reading.

J.-C. GAUTHIER

Senior VP at AREVA NP, "Plants sector" ICAPP 2007 Technical Program Chair

\section{International Technical Program Committee:}

Akira Omoto (IAEA), Toshikazu Takeda (Osaka University - Japan), Trever Cook (DOE - United States), Travis W. Knight (University of South Carolina - United States), Graham Fairhall (BNFL United Kingdom), Nam-Jin Cho (KNS - Korea)

\section{Equipe de coordination technique/Program Track Leaders:}

1 - Water-Cooled Reactor Programs and Issues : Bernard Debontride (AREVA NP)

2 - High-Temperature Gas Cooled Reactors : Michel Lecomte (AREVA NP)

3 - LMFR \& Longer Term Reactor Programs : Claude Renault (CEA)

4 - Operation, Performance \& Reliability Management : Philippe Taurin (EDF), Isabelle Morlaes (AREVA NP)

5 - Plant Safetv Assessment and Regulatory Issues : Christian Clément (EDF)

6 - Thermal Hydraulic Analysis and Testing : Bernard Faydide (CEA)

7 - Fuel Cycle and Waste Management - Dominique Grenèche (AREVA NC)

8 - Materials and Structural Issues : Françoise Touboul (CEA)

9 - Nuclear Energy and Sustainability : Bernard Bonin (CEA)

10 - Near-Term Deployment Context Issues : Alain Calamand (AREVA NP)

11 - Reactor Physics and Analyses : Anne Nicolas, Christine Poinot (CEA)

12 - Innovative and Space Power : Xavier Raepsaet (CEA) 